\title{
INTEGRATED FARMING AND ITS IMPACT ON FARMERS' LIVELIHOOD IN BANGLADESH
}

\author{
M. T. Uddin ${ }^{* 1}$, M. A. Khan ${ }^{2}$ and M. M. Islam ${ }^{3}$ \\ Department of Agricultural Economics, Bangladesh Agricultural University \\ Mymensingh-2202, Bangladesh
}

\begin{abstract}
The study was conducted to identify the present status of integrated farming and its impacts on farmers' livelihood in comparison to mixed farming. Following two stages sampling procedure, a total of 420 farmers (210 for integrated farming and 210 for mixed farming) were selected from seven study areas of six districts on the basis of having intervention from different NARS institutes and without having any intervention from any organization. Descriptive statistics like sum, average, percentage, etc. were derived and calculated for analyzing the socioeconomic data. Propensity score matching (PSM) were applied with Kernel matching and Radius matching methods to evaluate the impact of integrated farming on farmers' employment creation and income generation. The highest employment duration for male was 152.5 man-days/year for the farming system C-L-P-F-H under integrated farms and for mixed farms, it was 104.5 man-days/year. The average total income of the integrated farms was Tk. 124839 and for mixed farms, it was Tk. 99641. Average calorie intake of food secure households was $2927.83 \mathrm{kcal}$ and $2839.14 \mathrm{kcal}$ for integrated farming and mixed farming which is higher than the national average calorie intake (i.e., $2122 \mathrm{kcal}$ ). To assess the livelihood pattern through asset pentagon approach, noteworthy improvement was found based on different capitals of farm households practicing integrated farming in comparison to mixed farming. Finally, based on different problems, a constraint facing index was calculated in order to suggest policy recommendations.
\end{abstract}

Keywords: Employment, income, integrated farming, livelihood, mixed farming, poverty

\footnotetext{
* Corresponding author email: tajbau@yahoo.com

${ }^{1}$ Professor, Department of Agricultural Economics, Bangladesh Agricultural University, Mymensingh-2202, Bangladesh

${ }^{2}$ Associate Professor, Department of Agricultural Finance, Bangladesh Agricultural University, Mymensingh-2202, Bangladesh

${ }^{3}$ Lecturer, Department of Agricultural Economics, Bangladesh Agricultural University, Mymensingh-2202, Bangladesh
} 


\section{INTRODUCTION}

It is often argued that the future development of Bangladesh depends particularly on the agriculture sector which is the mainstay of the economy and also considered as the prominent source of employment for the incremental labour force. However, farmers' are engaged in producing field crops and homestead farming like vegetables and fruit production, fish culture, livestock and poultry rearing along with some other non-farm activities. These activities are interlinked and together they constitute integrated farming. Integrated farming is a concept and principle of two or more farm enterprises in a farm having strong cohesive and interactive relationship for production and consumption activities and in sharing and utilizing resources (Hossain et al., 2002). To increase farm income, the adoption of integrated farming is being encouraged in Bangladesh under various development programmes.

Since there is no scope to increase the area under cultivated land, the only way to increase employment, farm production and income and thereby to improve livelihood of the farming community is to increase the productivity of land through integrated farming. It is a way to supply necessary commodities to the households and to maximize farm income as well as to maintain environment friendly farming.

The National Agricultural Research Systems and the Bangladesh Agricultural University have been conducting farming system research and development since 1980s under the umbrella of the Bangladesh Agricultural Research Council and a compendium of technologies prepared from the research findings and technology bulletins were prepared for the farmers. But all these studies were intervention oriented and location specific mainly devoted to technology generation and practice development. A modest attempt has been made here to review the previous research studies which are: Sharmin et al. (2012) conducted a study on socioeconomic analysis of alternative farming systems in improving livelihood security of small

farmers in selected areas of Bangladesh which revealed that small farmers included more enterprises in farm practices to have better food security, higher income and improving livelihood. Uddin and Takeya (2006) examined a study on employment patterns and income generation of farm households in integrated farming of Bangladesh. The finding implied that integrated farming is important not only for employment creation, but also for promoting the overall economic condition.

The above review indicates that most of the studies discussed the performance of the integrated farming along with technical development, farmers' livelihood changes, agro-economic practices and production of different crops, livestock, poultry and fishery. Very little attempts have so far been made to examine the nature, extent and impact of integrated farming on farm households' livelihood. Therefore, the present study makes substantial contribution to the literature in this field. The overall goal of this research is to identify the present status of integrated farming and its impact on farmers' livelihood in comparison to mixed farming in Bangladesh. The specific objectives of the research were as follows: (i) to identify the present status of 
integrated farming in relation to mixed farming; (ii) to assess the impacts of integrated farming on farmers' employment creation, income generation, poverty reduction and livelihood patterns in comparison to mixed farming; and (iii) to suggest policy options for overcoming constraints and exploring possible opportunities.

\section{MATERIALS AND METHODS}

The present study was conducted at farming system research (FSR) sites of four institutions of Bangladesh. Altogether 420 sample farmers were interviewed for the study. Firstly, 210 farmers practicing integrated farming under different institutions from seven selected FSR sites (i.e., 30 farmers from each site) and secondly, 210 farmers practicing mixed farming from the village after the next one of each FSR site (i.e., 30 farmers from each village) were selected for data and information. All possible efforts were made to ensure the collection of reasonably accurate data from the selected farmers through face-to-face interview on recall basis. Moreover, focus group discussions (FGD) were conducted in every selected location. The primary data for one year farming operations (January-December 2013, which covered three rice crop seasons namely, Aus, Aman and Boro as well as other farm enterprises such as, livestock rearing, poultry rearing, fish culture and homestead enterprise) along with non-farm activities were collected. Secondary information sources in the form of handouts, reports, publications, notifications, etc. having relevance with this study were also consulted.

\section{Model specification}

A combination of descriptive statistics, mathematical and statistical techniques was used to achieve the objectives. Descriptive statistics like sum, average, percentage and ratio were calculated to examine the socioeconomic characteristics of the sample farmers.

\section{Impact evaluation}

To evaluate the impact of integrated farming on farmers' employment creation and income generation, techniques of propensity score matching (PSM) were applied with Kernel and Radius matching methods.

\section{Kernel matching method}

Kernel matching is simply a Kernel density function. In this method, all of the observations in the comparison group inside the common support region are used. Kernel matching method can be written as follows:

$$
\mathrm{E}(\Delta \mathrm{Y})=\frac{1}{\mathrm{~N}} \sum_{\mathrm{i} \in \mathrm{T}}\left[\mathrm{Y}_{\mathrm{i}, 1}-\frac{\sum_{\mathrm{j}=1}^{\mathrm{N}_{\mathrm{i}}^{\mathrm{C}}} \mathrm{Y}_{\mathrm{j}, 0}^{\mathrm{i}} \mathrm{K}\left(\frac{\mathrm{P}\left(\mathrm{x}_{\mathrm{j}, 0}^{\mathrm{i}}\right)-\mathrm{P}\left(\mathrm{N}_{\mathrm{i}, 1}\right)}{\mathrm{b}_{\mathrm{W}}}\right)}{\sum_{\mathrm{j}=1}^{\mathrm{N}_{\mathrm{i}}^{\mathrm{C}} \mathrm{K}} \mathrm{K}\left(\frac{\mathrm{P}\left(\mathrm{N}_{\mathrm{j}, 0}^{\mathrm{i}}\right)-\mathrm{P}\left(\mathrm{N}_{\mathrm{i}, 1}\right)}{\mathrm{b}_{\mathrm{W}}}\right)}\right]
$$


where $\mathrm{T}$ is the set of observations that are in the project (treatment group), and $\mathrm{N}$ is the number of treated cases; $\mathrm{Yi}_{1}$ and $\mathrm{Xi}_{1}$ are the dependent and independent variables for the $i^{\text {th }}$ treated case; $\mathrm{Y}_{\mathrm{j}, 0}^{\mathrm{i}}$ and $\mathrm{X}_{\mathrm{j}, 0}^{\mathrm{i}}$ are the dependent and independent variables for the $j^{\text {th }}$ comparison/control case that is within the neighbourhood of treatment case i, i.e., for which $\left|\mathrm{P}\left(\mathrm{X}_{\mathrm{j}_{0} 0}^{\mathrm{i}}\right)-\mathrm{P}\left(\mathrm{X}_{\mathrm{i}, 1}\right)\right|<\mathrm{bw} / 2 ; \mathrm{N}_{\mathrm{i}}^{\mathrm{C}}$ is the number of comparison cases within the neighbourhood of $\mathrm{i} ; \mathrm{K}(\bullet)$ is a kernel function; and bw is a bandwidth parameter. In practice, the choices of $\mathrm{K}(\bullet)$ and bw are somewhat arbitrary.

\section{Radius matching method}

Radius matching method can be written as follows:

$$
\mathrm{R}^{\mathrm{M}}=\frac{1}{\mathrm{~N}^{\mathbb{T}}} \sum_{\mathrm{i} E \mathrm{~T}} \mathrm{Y}_{\mathrm{i}}^{\mathrm{T}}-\frac{1}{\mathrm{~N}^{\mathbb{T}}} \sum_{\mathrm{j}}=\mathrm{C} \mathrm{W}_{\mathrm{j}} \mathrm{Y}_{\mathrm{j}}^{\mathrm{C}}
$$

Where, the weights $w_{j}$ are defined as $w_{\mathrm{j}}=\sum_{\mathrm{i}} \mathrm{w}_{\mathrm{ij}}$;

$\mathrm{Y}^{\mathrm{T}}=$ Output of treated individual; and

$\mathrm{Y}^{\mathrm{C}}$ indicates output of control individual.

\section{Poverty measure}

The mathematical representations are as follows:

$$
\mathrm{Z}_{\mathrm{i}}=\mathrm{Y}_{\mathrm{i}} / \mathrm{R}
$$

Where,

$\mathrm{Z}_{\mathrm{i}}=$ Food security index for $\mathrm{i}$-th household which takes the value of 1 for food secure and that of 0 for food insecure householdsand, that is

$Z_{i}=1$ for $Y i$ is greater than or equal to $R$; and $Z_{i}=0$ for $Y i$ less than $R$.

$\mathrm{Y}_{\mathrm{i}}=$ Daily per capita calorie intake of $\mathrm{i}$-th households;

$\mathrm{R}=$ Daily per capita calorie required for i-th households; and $\mathrm{i}=1,2,3 \ldots \ldots \ldots, 30$.

Based on the household food security index (Z), food insecurity gap/ surplus index $(\mathrm{P})$ and the head count ratio $(\mathrm{H})$ were calculated. Food insecurity gap measures the extent to which households are food insecure and surplus index measures the extent by which food secure households exceeded food security line. This index is given as:

$$
\mathrm{P}=\frac{1}{\mathrm{M}} \sum_{\mathrm{i}=1}^{\mathrm{m}} \mathrm{Gi}
$$

Where,

$\mathrm{P}=$ Food insecurity gap or surplus index;

$M=$ Number of households that are food secure (for surplus index) or 
food insecure (for food insecurity gap); and

$\mathrm{G}_{\mathrm{i}}=$ Per capita calorie intake deficiency (or surplus) faced by i-th household.

$$
\mathrm{G}_{\mathrm{i}}=\left(\frac{\mathrm{Yi}-\mathrm{R}}{\mathrm{R}}\right)
$$

The head count ratio $(\mathrm{H})$ measures the percentage of the population of households that are food secure or insecure. This is defined as:

$$
\mathrm{H}=\frac{\mathrm{M}}{\mathrm{N}}
$$

Where,

$\mathrm{H}=$ head count ratio;

$M=$ Number of households that are food secure (for surplus index) or food insecure (for food insecurity gap); and

$\mathrm{N}=$ Number of households in the sample.

\section{Constraint facing index}

An overall constraints score in integrated and mixed farming was computed for each farmer by adding their constraint scores in all 15 constraint items. The possible range of constraints facing score for each constraint could be 0 to 3 and possible range of overall constraints facing for score for 15 constraints could range from 0 to 45 . A constraint facing index (CIF) for each 15 selected constraints was computed by using the following formula:

$$
\begin{aligned}
& C F I=\left(C_{h} \times 3\right)+\left(C_{m} \times 2\right)+\left(C_{1} \times 1\right)+\left(C_{n} \times 0\right) \\
& \text { Where, } \\
& C_{h}=\text { Number of responses indicating high constraint; } \\
& C_{m}=\text { Number of responses indicating medium constraint; } \\
& C_{1}=\text { Number of responses indicating low constraint; and } \\
& C_{n}=\text { Number of responses indicating no constraint. }
\end{aligned}
$$

Constraint facing index (CFI) for any of the selected constraint could range from 0 to 495 for integrated farming, where, 0 indicated no constraint facing and 495 indicated highest constraint facing and 0 to 477 for mixed farming, where, 0 indicated no constraint facing and 477 indicated highest constraint facing.

\section{RESULTS AND DISCUSSION}

\section{Socioeconomic Characteristics and Status of Integrated and Mixed Farming}

To identify the status of integrated farming in relation to mixed farming, it is essential to know the socioeconomic characteristics of the sample farmers. This part provides information on socioeconomic characteristics of selected farm households 
such as area and number of farm enterprises and educational attainment for the members of selected households.

\section{Distribution of sample farm households}

Fourteen types of farming systems were found in the research sites among which five farming systems were common in both integrated farming and mixed farming (Table 1). These farming systems were: crop-livestock-poultry-fishhomestead, crop-livestock-poultry-homestead, crop-livestock-fish-homestead, crop-poultry-fish-homestead, and crop-livestock-homestead. As most of the farmers were practicing these five types of farming systems, these are considered as major farming systems. Remaining nine types of farming systems are treated as minor farming systems. From the table 1, it is found that crop-livestock-poultryhomestead farming system was the most popular in both integrated farming and mixed farming systems and their percentage were 37.1 and 27.6, respectively. This result is supported by Islam et al. (2012) where the authors found that C-L-P-FC, CL-FC-LS, FC-LS-C-L, C-L-FC, C-LP were the major farming systems in Dingapota haor area of Netrokona district.

\section{Area and number of farm enterprises of sample farm households}

Agricultural enterprises cultivated by the farm households are shown in Table 2 which includes both major and minor categories of farming systems. The average crop area under integrated and mixed farm was 0.43 ha and 0.50 ha for major farming systems and 0.38 ha and 0.45 ha for minor farming systems, respectively. The number of livestock and poultry bird was higher in integrated farm than in mixed farm. The results also supported by Ahmed et al. (2011). The researchers found that the highest average farm size was 0.33 ha in integrated farming followed by rice monoculture 0.31 ha and alternate farming 0.29 ha.

\section{Educational status of sample farm households}

All sample farmers were divided into five categories i.e., illiterate, primary, secondary, higher secondary and graduation and above education. It was evident that 18.2 percent integrated farms and 23.3 percent mixed farms were illiterate. A majority of the sample farmers (38.2 percent and 42.1 percent for integrated farms and mixed farms, respectively) had only primary level of education. A negligible portion of members had higher secondary and graduation and above.

\section{Incentives provided by different institutes to FSR sites}

It was found from the study areas that farmers under integrated farming got different types of facilities from the NARS institutes namely, Bangladesh Agricultural Research Institute, Bangladesh Rice Research Institute, Bangladesh Sugarcane Research Institute, etc. This facility included cash incentives and kind incentives. Cash incentives included free crop and vegetables seed, fertilizer, chick, fingerlings, lime and medicine, fruit plants, etc. and kind incentives included training, monitoring, motivation and veterinary services. On an average, integrated farms 
received cash incentives of Tk. 1944 and kind incentives equivalent to monetary value of Tk. 1494. These types of cash and kind incentives led recipient farmers to become more beneficial than the farmers under mixed farming (Table 3).

\section{Employment pattern on yearly basis for farm households}

The average working hours/day for male labour was 6.4 and 6.2, and female labour was 3.8 and 3.5, respectively under the integrated and mixed farming. Table 4 revealed that, on an average, male and female labour working duration was 147.0 and 112.9 and 96.7 and 59.2 man-days/year, respectively for integrated and mixed farming in respect of farming systems. Uddin and Takeya (2005) acknowledged that integrated farming as a good source of increased income and provides increased working hours per week as well as promote the overall economic condition.

\section{Annual income of sample farmers}

It is observed from Table 5 that the average total income of the integrated farms was Tk. 124839 and for mixed farms, it was Tk. 99641. The income figure of integrated farming is higher than the national average of Tk. 115776 (BBS, 2010). Considering the farming systems, farmers practicing C-L-H system earned highest annual income (Tk. 155892) under integrated farming and in case of mixed farming, farmers practicing C-L-P-F-H system got highest annual income (Tk. 138542) than other farming systems. This result is slightly similar with Uddin and Takeya (2005) who found that income from non-agricultural enterprises is higher for farmers in conventional farming compared to those of integrated farming in respect of farm sizes. It was calculated that change in annual income of the integrated farms was increased by the amount of Tk. 25198 in the study areas due to intervention which is statistically significant at 10 percent level.

\section{Overall employment creation and income generation of farm households}

Overall employment creation and income generation of farm households is shown in table 6 which reveals that integrated farming created comparatively more employment and earned higher farm and non-farm income considering major and minor farming systems in the study areas. Table 7 reveals that overall employment opportunities were increased significantly at 1 percent level by the duration of 61 to 62 man-days in the integrated farming compared to mixed farming.

Based on Kernel and Radius matching methods, the average farm household income of the integrated farming was increased by Tk. 34814 to Tk. 36157 per year compared to mixed farming which is statistically significant at $1 \%$ level. On the other hand, non-farm income was decreased slightly but it is not statistically significant in both the methods. Consequently, total household income was increased significantly at $1 \%$ level for integrated farming compared to mixed farming which is Tk. 32614 and Tk. 34647 based on Kernel and Radius propensity score matching methods, respectively (Table 7). 


\section{Poverty situation of the sample households}

The food security index for integrated farm households was 1.12 and for mixed farm households, it was 0.92 ; the value of this index for food secure households was 1.37 for integrated farming and for mixed farming, it was 1.33 whereas for food insecure households, it was 0.90 and 0.92 , respectively. Both the integrated and mixed farm households in the study areas could be regarded as food secure given the fact that 89.0 percent integrated farms and 78.0 percent mixed farms of the sample households were able to meet the required calorie intake of 2,122 kcal per capita per day while 11.0 percent and 22.0 percent as food insecure households, respectively (Table 8). Average calorie intake of food secure households was $2927.83 \mathrm{kcal}$ and $2839.14 \mathrm{kcal}$ for integrated farming and mixed farming which is higher than the national average calorie intake (i.e., $2122 \mathrm{kcal}$ ). The food insecurity gap/surplus index shows that the food secure households exceeded the food poverty line by 6.0 percent for integrated farming and 10.0 percent for mixed farming, while food insecure households fell short of required calorie intake by 8.0 percent and 7.0 percent, respectively. Ahmed et al. (2011) found that integrated rice-fish farming can play an important role in increasing food production, as the integrated farming system is better than rice monoculture in terms of resource utilization, diversity, productivity and both the quality and quantity of the food produced.

\section{Livelihood patterns of farm households}

A livelihood comprises the capabilities, assets (stores, resources, claims and access) and activities required for a means of living: a livelihood is sustainable which can cope with and recover from stresses and shocks, maintain or enhance it capabilities and assets and provide sustainable livelihood opportunities for the next generation and which contributes net benefits to other livelihoods at the local and global levels in the long and short term (Chambers et al., 1992).

The asset pentagon approach shows that there is a noteworthy improvement based on different capitals (namely, human capital, social capital, natural capital, physical capital and financial capital) of farm households practicing integrated farming in comparison to mixed farming (Table 9).

Human capital: Table 9 represents the changing nature of different components of human capital in farmers' livelihoods. Majority of the farmers under integrated farming reported that quality of the components of human capital has increased over the periods through gaining education and knowledge, improving health condition, more access to information, better training and development of skill in all the selected areas.

Social capital: In this study, involvement in social group, political involvement, self-managerial capability and social access were considered as the components of social capital. Table 9 shows the positive trends of social assets in the integrated farm households. Almost all the farmers' involvements in different social 
groups, their managerial capacity through integrated farming had improved.

Natural capital: Cultivable land, using open water resources and forests were addressed to determine the changing natural capital aspect. Quantity of cultivable land had increased in integrated farm households whereas in mixed farm households, it fluctuated over time. Access to open water resources also showed increasing trend in integrated farmers. Majority of the farm households had constant access to different types of natural capital.

Financial capital: Table 9 shows the changing trend of financial capital of the integrated farm households. Cash in hand, savings and liquid assets had increased for the integrated farm households. However, the rate of increase was not estimated. Farmers' income had increased and they were able to have more cash savings and liquid assets through integrated farming. Remittances and donation were constant for the integrated farm households.

Physical capital: The changing state of physical assets has been shown in table 9. Almost all the asset category showed positive trends in the integrated farm households. In all of the farming systems, most of the farmers had tin roofed houses. Percentages of respondents having decreased trend of straw roof houses increased gradually with time. Likely, percentages of farm households having tube-well, pucca and kacha toilet increased significantly in all the research sites. Maximum respondents were found to have electricity facilities.

\section{Constraint facing index (CFI)}

The computed CFI of the 15 constraints ranged from 70 to 276 for integrated farming and 130 to 334 for mixed farming. Majority of the farmers mentioned that low price of outputs, non-availability and high price of HYV seed and scarcity of concentrate feed and fodder arethe serious problems in the study areas and the computed value of CFI was 276, 264 and 235 for integrated farming and for mixed farming these were, 334, 295, and 28, respectively. The extent of high price of fertilizers and pesticides and non-availability and high price of fingerlings are also more remarkable problems for mixed farming than the integrated farming. Due to lack of education and training facilities, farmers were using traditional method of cultivation and getting lower yield. The high price of irrigation was another problem of cultivating different crops. This problem arises mainly due to high price of electricity.

Non-farm employment opportunity has been created to a large extent and labourers in the study areas migrated from agriculture farming to non-farm activities for higher income. Therefore, the scarcity of labour along with their higher wage rate is found to a large extent in mixed farming compared to integrated farming in different cropping seasons that ultimately hamper the whole process of cultivation. To prevent certain diseases and to run livestock and poultry production smoothly, farmers required medicine and vaccine timely. 


\section{CONCLUSIONS AND POLICY RECOMMENDATIONS}

The study reveals that crop-livestock-poultry-homestead farming system was the most popular in both integrated and mixed farming systems. The study also concludes that integrated farming has the potential of increasing farmers' income and employment creation over the mixed and traditional farming practices in the study areas. The study also reveals that the extent of food security situation was much better among the integrated farm households than the mixed farm households. Poverty was decreased in case of integrated farming compared to mixed farming. Worth mentioning improvements were found based on different capitals (namely, human capital, social capital, natural capital, physical capital and financial capital) of farm households practicing integrated farming in comparison to mixed farming. Considering the findings of the study, some important policy recommendations have been arisen which are: special incentives from Department of Agricultural Extension (DAE) on irrigation and fertilizer for small and marginal farmers are necessary to enhance the productivity and profitability. Department of Fisheries (DoF) should monitor seed and feed company/hatchery to ensure good quality fingerlings; and veterinary services for dairy cattle and poultry birds should be ensured by Department of Livestock Services (DLS) timely at village level. Training program on production technologies, harvesting, processing, storage and transportation should be offered by different institutes for increasing skill of the farmers so that they can obtain and apply knowledge for field crops, livestock production and fish culture as well.

\section{REFERENCES}

Ahmed, N. and Garnett, S. T. 2011. Integrated rice-fish farming in Bangladesh: meeting the challenges of food security. Food Security, Original Paper, Springer, 3 (1), Pp. 81-92

BBS, 2010. Statistical Yearbook of Bangladesh, Bangladesh Bureau of Statistics, Statistics Division, Ministry of Planning, Government of the People's Republic of Bangladesh, Dhaka

Chambers, R. and Conway, G. 1992. Sustainable rural livelihoods: practical concepts for the $21^{\text {st }}$ century. Discussion paper 296, Institute of Development Studies, Brighton, UK: IDS

Hossain, S. M. A., Ahmed, S., Halim, A., Talukder, M. S., Islam, M. S. and Bhuiya, M. S. U., 2002. Fact searching and intervention 1999-2001. Studies on integrated farming. FSES Publication No. 78. Farming Systems and Environmental Studies, Bangladesh Agricultural University, Mymensingh

Islam, S., Uddin, M. T., Akteruzzaman, M., Rahaman, M. and Haque, M. A., 2011. Profitability of alternate farming systems in Dighapota haor area of Netrokona district. Progressive Agriculture, 22 (1\&2) Pp. 223-239

Mahmud, H., 1998. A comparative analysis of rice-cum-fish-prawn and fish-cum prawn culture in some selected areas under sadarthana of Gopalgong district. M.S. Thesis, Department of Agricultural Economics, Bangladesh Agricultural University, Mymensingh 
Sharmi, S., Islam, M. S. and Hasan, M. K., 2012. Socioeconomic analysis of alternative farming systems in improving livelihood security of small farmers' in selected areas of Bangladesh. The Agriculturists, 10 (1) Pp. 51-63

Uddin, M. T. and Takeya, H., 2005. Economic analysis of integrated farming by agricultural enterprise in Mymensingh district of Bangladesh. Journal of Rural Development Studies, 16 (1) Pp. 40-49

Uddin, M. T. and Takeya, H., 2006. Comparative study on integrated farming in Bangladesh and other countries. Bangladesh Journal of Agricultural Economics, 29 (1\&2) Pp. 8192 
Table 1. Distribution of sample farm households

\begin{tabular}{|c|c|c|c|c|}
\hline \multirow[t]{2}{*}{ Farming systems } & \multicolumn{2}{|c|}{ Integrated farming } & \multicolumn{2}{|c|}{ Mixed farming } \\
\hline & $\begin{array}{c}\text { No. of } \\
\text { farm } \\
\text { household }\end{array}$ & $\begin{array}{l}\text { Percentage } \\
\quad(\%)\end{array}$ & $\begin{array}{l}\text { No. of farm } \\
\text { household }\end{array}$ & $\begin{array}{c}\text { Percentage } \\
(\%)\end{array}$ \\
\hline $\begin{array}{l}\text { Crop-Livestock-Poultry-Fish-Homestead } \\
\text { (C-L-P-F-H) }\end{array}$ & 45 & 21.4 & 17 & 8.0 \\
\hline $\begin{array}{l}\text { Crop-Livestock-Poultry-Homestead (C-L-P- } \\
\text { H) }\end{array}$ & 78 & 37.1 & 58 & 27.6 \\
\hline Crop-Livestock-Fish-Homestead (C-L-F-H) & 10 & 4.8 & 32 & 15.4 \\
\hline Crop-Poultry-Fish-Homestead (C-P-F-H) & 12 & 5.7 & 31 & 14.8 \\
\hline Crop-Livestock-Homestead (C-L-H) & 20 & 9.5 & 21 & 10.0 \\
\hline Crop-Livestock-Poultry-Fish (C-L-P-F) & 5 & 2.4 & 2 & 1.0 \\
\hline Crop-Livestock-Fish (C-L-F) & 2 & 0.9 & 3 & 1.4 \\
\hline Crop-Livestock-Poultry (C-L-P) & 7 & 3.3 & 7 & 3.3 \\
\hline Crop-Poultry-Homestead (C-P-H) & 6 & 2.9 & 5 & 2.4 \\
\hline Crop-Poultry-Fish (C-P-F) & 1 & 0.5 & 4 & 1.9 \\
\hline Crop-Fish-Homestead (C-F-H) & 8 & 3.8 & 9 & 4.3 \\
\hline Crop-Livestock (C-L) & 8 & 3.8 & 8 & 3.8 \\
\hline Crop-Fish (C-F) & 1 & 0.6 & 6 & 2.8 \\
\hline Crop-Homestead (C-H) & 7 & 3.3 & 7 & 3.3 \\
\hline Total & 210 & 100.0 & 210 & 100.0 \\
\hline
\end{tabular}

Source: Field survey, 2013. 
Table 2. Area and number and educational status of farm households

\begin{tabular}{|c|c|c|c|c|c|}
\hline \multirow[t]{2}{*}{ Variables } & \multirow[t]{2}{*}{ Class } & \multicolumn{2}{|c|}{$\begin{array}{l}\text { Integrated farming } \\
\text { system }\end{array}$} & \multicolumn{2}{|c|}{ Mixed farming system } \\
\hline & & Major & Minor & Major & Minor \\
\hline \multirow{6}{*}{$\begin{array}{l}\text { Area and } \\
\text { number of } \\
\text { farm } \\
\text { enterprises } \\
\text { (Average) }\end{array}$} & No. of farmers & 33 & 5 & 32 & 10 \\
\hline & Crop area (ha) & 0.43 & 0.38 & 0.50 & 0.45 \\
\hline & Livestock (No.) & 2.98 & 1.81 & 2.66 & 1.63 \\
\hline & Poultry (No.) & 8.20 & 6.50 & 4.40 & 5.60 \\
\hline & Fish area (ha) & 0.09 & 0.07 & 0.08 & 0.06 \\
\hline & Homestead area (ha) & 0.10 & 0.06 & 0.09 & 0.04 \\
\hline \multirow{5}{*}{$\begin{array}{l}\text { Educational } \\
\text { status of the } \\
\text { sample } \\
\text { farmers }\end{array}$} & Illiterate & \multicolumn{2}{|c|}{$30(18.2)$} & \multicolumn{2}{|c|}{$37(23.3)$} \\
\hline & Primary & \multicolumn{2}{|c|}{$63(38.2)$} & \multicolumn{2}{|c|}{$67(42.1)$} \\
\hline & Secondary & \multicolumn{2}{|c|}{$54(32.7)$} & \multicolumn{2}{|c|}{$48(30.2)$} \\
\hline & Higher secondary & \multicolumn{2}{|c|}{$17(10.3)$} & \multicolumn{2}{|c|}{$4(2.5)$} \\
\hline & Graduation and above & \multicolumn{2}{|c|}{$1(0.6)$} & \multicolumn{2}{|c|}{$3(1.9)$} \\
\hline
\end{tabular}

Source: Field survey, 2013.

Note: Figures within the parentheses indicate percentage of total.

Table 3. Incentives (in Taka/Farm) provided by different institutes to FSR sites under major farming systems

\begin{tabular}{|l|c|c|c|c|c|}
\hline Items & C-L-P-F-H & C-L-P-H & $\begin{array}{c}\text { C-L-F- } \\
\text { H }\end{array}$ & C-P-F-H & C-L-H \\
\hline \multicolumn{7}{|c|}{ Cash incentives } \\
\hline Seed (Crops and vegetables) & 700 & 650 & 600 & 680 & 650 \\
\hline Fertilizer & 650 & 700 & 650 & 620 & 700 \\
\hline Chick & 150 & 150 & & 200 & \\
\hline Fingerlings & 400 & - & 350 & 320 & - \\
\hline Lime and medicine & 120 & - & 150 & 150 & - \\
\hline Fruit plants & 150 & 300 & 200 & 180 & 300 \\
\hline
\end{tabular}




\begin{tabular}{|l|c|c|c|c|c|}
\hline Total & 2170 & 1800 & 1950 & 2150 & 1650 \\
\hline Each IFS average & 361.67 & 450 & 390 & 358.33 & 550 \\
\hline Overall average & \multicolumn{5}{|c|}{1944} \\
\hline \multicolumn{7}{|c|}{ Kind incentives } \\
\hline Training & 350 & 300 & 250 & 200 & 310 \\
\hline Monitoring & 550 & 450 & 375 & 425 & 430 \\
\hline Motivation & 220 & 410 & 200 & 300 & 270 \\
\hline Veterinary services & 520 & 500 & 450 & 440 & 520 \\
\hline Total & 1640 & 1660 & 1275 & 1365 & 1530 \\
\hline Each IFS average & 410 & 415 & 318.7 & 341.25 & 382.5 \\
\hline Overall average & & & 5 & & \\
\hline
\end{tabular}

Source: Authors' calculation based on field survey, 2013.

Table 4. Employment pattern on yearly basis for farm households under major farming systems

\begin{tabular}{|l|c|c|c|c|c|c|}
\hline \multirow{2}{*}{ Farming systems } & \multicolumn{2}{|c|}{ Working hours/ day } & Duration (man-days/year) & \multicolumn{2}{c|}{ Wage/day } \\
\cline { 2 - 7 } & Male & Female & Male & Female & Male & Female \\
\hline \multicolumn{7}{|c|}{ Integrated farming } \\
\hline Total & 32.2 & 18.9 & 734.8 & 564.5 & 1155 & 848.3 \\
\hline Average & 6.4 & 3.8 & 147.0 & 112.9 & 231.0 & 169.6 \\
\hline & 31 & 17.4 & 483.5 & 296 & 1155 & 848.3 \\
\hline Total & 6.2 & 3.5 & 96.7 & 59.2 & 231.0 & 169.6 \\
\hline Average & \multicolumn{7}{|c|}{ Mixed farming } \\
\hline
\end{tabular}

Source: Field survey, 2013. 
SAARC J. Agri., 13(2):61-79 (2015)

Table 5. Income from various sources under major farming systems (in Taka/Farm)

\begin{tabular}{|c|c|c|c|c|c|c|c|c|c|c|c|c|}
\hline \multirow{2}{*}{$\begin{array}{l}\text { Sources of } \\
\text { income }\end{array}$} & \multicolumn{6}{|c|}{ Integrated farming } & \multicolumn{6}{|c|}{ Mixed farming } \\
\hline & \begin{tabular}{|l} 
C-L-P- \\
F-H
\end{tabular} & C-L-P-H & \begin{tabular}{|c|} 
C-L-F- \\
$\mathrm{H}$
\end{tabular} & C-P-F-H & C-L-H & Average & $\begin{array}{l}\text { C-L-P- } \\
\text { F-H }\end{array}$ & $\begin{array}{c}\text { C-L-P- } \\
\text { H }\end{array}$ & $\begin{array}{c}\text { C-L-F- } \\
\text { H }\end{array}$ & $\begin{array}{c}\text { C-P-F- } \\
\mathrm{H}\end{array}$ & C-L-H & Average \\
\hline \multicolumn{13}{|c|}{ Farm activities } \\
\hline Crop & 44791 & 38527 & 33049 & 31267 & 64099 & 42347 & 40136 & 28606 & 55536 & 23560 & 44652 & 38498 \\
\hline Livestock rearing & 35916 & 25740 & 31325 & - & 39689 & 26462 & 27036 & 27456 & 20655 & - & 30081 & 21022 \\
\hline Poultry rearing & 15481 & 12720 & - & 21120 & - & 9815 & 8395 & 11155 & - & 5625 & - & 5025 \\
\hline Fish farming & 12824 & - & 18068 & 11064 & - & 8517 & 11082 & - & 8679 & 13073 & - & 6734 \\
\hline $\begin{array}{l}\text { Homestead } \\
\text { farming }\end{array}$ & 12233 & 6201 & 6717 & 3919 & 4004 & 6758 & 9893 & 1605 & 2508 & 6252 & 4582 & 5022 \\
\hline Total farm income & 121245 & 83188 & 89159 & 67370 & 107792 & 93899 & 96542 & 68822 & 87378 & 48510 & 79315 & 76301 \\
\hline \multicolumn{13}{|c|}{ Non-farm activities } \\
\hline Servicing & 12000 & 17000 & 13500 & - & 20000 & 12500 & 11000 & 20000 & 11000 & - & - & 8400 \\
\hline Small business & 8000 & 5000 & 12000 & 12600 & 15000 & 10520 & 18500 & 12500 & & 12500 & 8500 & 10400 \\
\hline Tailoring & - & & - & - & 5500 & 1100 & - & - & - & - & - & \\
\hline Labour selling & 8000 & 10500 & - & 8000 & 7600 & 6820 & 12500 & - & - & - & 10200 & 4540 \\
\hline $\begin{array}{l}\text { Total non-farm } \\
\text { income }\end{array}$ & 28000 & 32500 & 25500 & 20600 & 48100 & 30940 & 42000 & 32500 & 11000 & 12500 & 18700 & 23340 \\
\hline Total income & 149245 & 115688 & 114659 & 87970 & 155892 & 124839 & 138542 & 101322 & 98378 & 61010 & 98015 & 99641 \\
\hline $\begin{array}{l}\text { Change in total } \\
\text { income }\end{array}$ & \multicolumn{12}{|c|}{$25198\left(2.13^{*}\right)$} \\
\hline
\end{tabular}

Source: Authors' calculation based on field survey, 2013. * Significant at 10 percent level 
M. T. Uddin et al

Table 6. Employment creation and income generation from major and minor farming systems

\begin{tabular}{|c|c|c|c|}
\hline Farming systems & Items & Integrated farming & Mixed farming \\
\hline \multirow{4}{*}{$\begin{array}{l}\text { 1. Major farming systems } \\
\text { (Practiced by } 165 \text { samples of } \\
\text { integrated farm and } 159 \text { samples } \\
\text { of mixed farm) }\end{array}$} & Employment (man-days) & 129.9 & 77.9 \\
\hline & Farm income (Tk.) & 93899 & 76301 \\
\hline & Non-farm income (Tk.) & 30940 & 23340 \\
\hline & Total income (Tk.) & 124839 & 99641 \\
\hline \multirow{4}{*}{$\begin{array}{l}\text { 2. Minor farming systems } \\
\text { (Practiced by } 45 \text { samples of } \\
\text { integrated farm and } 51 \text { samples of } \\
\text { mixed farm) }\end{array}$} & Employment (man-days) & 114.7 & 60.4 \\
\hline & Farm income (Tk.) & 65358 & 48337 \\
\hline & Non-farm income (Tk.) & 33487 & 32145 \\
\hline & Total income (Tk.) & 98845 & 80482 \\
\hline \multirow{4}{*}{$\begin{array}{l}\text { 3. Total sample farm households } \\
\text { (Practiced by } 210 \text { integrated farm } \\
\text { and } 210 \text { mixed farm) }\end{array}$} & Employment (man-days) & 122.3 & 69.2 \\
\hline & Farm income (Tk.) & 79629 & 62319 \\
\hline & Non-farm income (Tk.) & 32214 & 27743 \\
\hline & Total income (Tk.) & 111842 & 90062 \\
\hline
\end{tabular}

Source: Authors' calculation, 2013. 
Table 7. Impact on farmers' employment creation and income generation

\begin{tabular}{|c|c|c|c|}
\hline $\begin{array}{l}\text { Matching method and } \\
\text { outcome }\end{array}$ & $\begin{array}{l}\text { Average treatment on treated } \\
\text { (ATT) }\end{array}$ & Standard error & t-value \\
\hline \multicolumn{4}{|c|}{ Employment (man-days) } \\
\hline Kernel matching & 61 & 20.88 & 2.89 \\
\hline Radius matching & 62 & 20.31 & 3.05 \\
\hline \multicolumn{4}{|c|}{ Farm income (Tk.) } \\
\hline Kernel matching & $34814 *$ & 6778 & 6.03 \\
\hline Radius matching & $36157 *$ & 7150 & 5.44 \\
\hline \multicolumn{4}{|c|}{ Non-farm income (Tk.) } \\
\hline Kernel matching & -2688 & 6576 & -0.31 \\
\hline Radius matching & -746 & 7822 & -0.09 \\
\hline \multicolumn{4}{|c|}{ Total household income (Tk.) } \\
\hline Kernel matching & 32614 & 5282 & 3.77 \\
\hline Radius matching & 34647 & 5394 & 3.93 \\
\hline
\end{tabular}

Source: Authors' calculation based on field survey, 2013.

Note: * Significant at 10 percent level. 
Table 8. Food security index for integrated farming and mixed farming

\begin{tabular}{|l|l|c|c|c|}
\hline \multirow{2}{*}{$\begin{array}{l}\text { Farming } \\
\text { system }\end{array}$} & \multicolumn{1}{|c|}{ Food security indices } & $\begin{array}{c}\text { Food secure } \\
\text { households }\end{array}$ & $\begin{array}{c}\text { Food insecure } \\
\text { households }\end{array}$ & All \\
\hline \multirow{3}{*}{$\begin{array}{l}\text { Integrated } \\
\text { farming }\end{array}$} & Food securitv index & 1.37 & 0.90 & 1.12 \\
\cline { 2 - 5 } & $\begin{array}{l}\text { Head count index } \\
\text { Per capita daily calorie availability }\end{array}$ & 2927.83 & 1963.10 & 2290.99 \\
\cline { 2 - 6 } & Food insecurity gap/Surplus index & 0.06 & -0.08 & - \\
\hline \multirow{2}{*}{ Mixed } & Food security index & 1.33 & 0.92 & 0.92 \\
\cline { 2 - 6 } & Head count index & 0.78 & 0.22 & - \\
\cline { 2 - 6 } & $\begin{array}{l}\text { Per capita daily calorie availability } \\
\text { (kcal) }\end{array}$ & 2839.14 & 2027.32 & 2240.62 \\
\cline { 2 - 6 } & Food insecurity gap/Surplus index & 0.10 & -0.07 & - \\
\hline
\end{tabular}

Source: Authors' estimation, 2013.

Table 9. Livelihood status of sample farmers (percentages of farmers reported)

\begin{tabular}{|l|c|c|}
\hline Asset categories & Integrated farmers (Increased) & Mixed farmers (Increased) \\
\hline Human capital & 77.60 & 28.40 \\
\hline Social capital & 62.25 & 28.50 \\
\hline Natural capital & 75.70 & 41.70 \\
\hline Physical capital & 77.70 & 36.10 \\
\hline Financial capital & 65.30 & 15.70 \\
\hline
\end{tabular}

Source: Authors' estimation, 2013. 
SAARC J. Agri., 13(2):61-79 (2015)

Table 10. Fifteen selected constraints along with constraints facing index and rank order

\begin{tabular}{|c|c|c|c|c|c|c|c|c|c|c|c|c|}
\hline \multirow{2}{*}{$\begin{array}{l}\text { Name of the } \\
\text { constraints }\end{array}$} & \multicolumn{6}{|c|}{ Integrated farming } & \multicolumn{6}{|c|}{ Mixed farming } \\
\hline & \multicolumn{4}{|c|}{$\begin{array}{l}\text { Extent of constraints } \\
\qquad(\mathrm{N}=165)\end{array}$} & CFI & $\begin{array}{l}\text { Rank } \\
\text { order }\end{array}$ & \multicolumn{4}{|c|}{$\begin{array}{l}\text { Extent of constraints } \\
\qquad(\mathrm{N}=159)\end{array}$} & CFI & $\begin{array}{l}\text { Rank } \\
\text { order }\end{array}$ \\
\hline Low price of outputs & 55 & 65 & 39 & 6 & 334 & 1 & 39 & 58 & 43 & 19 & 276 & 1 \\
\hline Scarcity of concentrate feed and fodder & 40 & 59 & 43 & 23 & 281 & 3 & 40 & 37 & 41 & 39 & 235 & 4 \\
\hline High price of fertilizers and pesticides & 37 & 43 & 41 & 44 & 238 & 4 & 38 & 31 & 47 & 43 & 223 & 5 \\
\hline $\begin{array}{l}\text { Non-availability and high price of } \\
\text { fingerlings }\end{array}$ & 31 & 39 & 44 & 51 & 215 & 5 & 26 & 31 & 45 & 57 & 185 & 7 \\
\hline Outbreak of diseases & 24 & 32 & 48 & 61 & 184 & 9 & 18 & 22 & 47 & 72 & 145 & 9 \\
\hline Transportation problem & 24 & 31 & 48 & 62 & 182 & 10 & 15 & 25 & 41 & 78 & 136 & 10 \\
\hline High price of irrigation & 21 & 34 & 45 & 65 & 176 & 11 & 17 & 21 & 38 & 83 & 131 & 11 \\
\hline Lack of storage and processing facilities & 15 & 28 & 54 & 68 & 155 & 13 & 11 & 16 & 31 & 101 & 96 & 13 \\
\hline Scarcity of labour & 13 & 25 & 55 & 72 & 144 & 14 & 7 & 11 & 35 & 106 & 78 & 14 \\
\hline High price of vaccine and medicine & 11 & 23 & 51 & 80 & 130 & 15 & 6 & 13 & 26 & 114 & 70 & 15 \\
\hline
\end{tabular}

Source: Field survey, 2013.

Note: CFI: Constraints Facing Index. 